\title{
PEMBUATAN KALIGRAFI ISLAM DARI BAHAN LIMBAH DI MAN 3 PADANGPANJANG
}

\author{
Zulhelman'), Nofrial'2), Purwo Prihatin'3), Sella Refialisa ${ }^{4)}$ \\ 1)Program Studi Seni Murni, Fakultas Seni Rupa dan Desain, Institut Seni Indonesia Padangpanjang \\ 2), 3) 4)Program Studi Seni Kriya, Fakultas Seni Rupa dan Desain, Institut Seni Indonesia \\ Padangpanjang \\ Jalan Bahder Johan Padangpanjang, Sumatera Barat, Kode Pos 27128 \\ Email : helmanzul@yahoo.com ${ }^{11}$, nofcraft@gmail.com ${ }^{2)}$, purwo prihatin@yahoo.co.id ${ }^{3),}$ \\ refialisasella@gmail.com ${ }^{4}$
}

\begin{abstract}
ABSTRAK
Pengetahuan dan ketrampilan pembuatan Kaligrafi Islam di MAN 3 Padangpanjang masih sangat rendah, baru berupa teknik tulis di media kertas. Dalam proses pembelajaran terkendala kemampuan guru di bidang pengetahuan kaligrafi, serta porsi waktu yang minim. Berangkat dari kondisi tersebut maka dilakukan kegiatan pelatihan pembuatan kaligrafi Islam dari bahan limbah kayu dan plastik, serta bahan lainnya. Guna membantu proses pembelajaran di bidang baca tulis Al Qur'an, serta menanamkan sikap kepedulian terhadap lingkungan pada peserta, dengan memanfaatkan limbah di lingkungan sekitar untuk kaligrafi.

Pengabdian menggunakan metode ceramah untuk menyampaikan pengetahuan secara umum tentang khat dan ilmu kaligrafi Islam, teknik perancangan dan pembuatan kaligrafi dari bahan limbah. Termasuk limbah apa saja yang dapat digunakan, baik kayu, plastik dan bahan lainnya. Demonstrasi digunakan untuk memberikan keterampilan langsung proses perancangan dan pembuatan kaligrafi. Metode tanya-jawab untuk diskusi. Pengabdian ini berhasil melatih peserta membuat kaligrafi di media triplek dengan teknik montase, dari bahan limbah cangkang kulit telur, serbuk kayu, pecahan cermin, batok kelapa, kulit batang pisang, limbah plastik dan limbah kertas, kayu perca dan kerikil. Serta kaligrafi pada media kertas dan kanvas, serta ketrampilan pembuatan jenis-jenis khat kaligrafi Islam.
\end{abstract}

Kata kunci : Pelatihan, Kaligrafi Islam, dan Limbah

\section{PENDAHULUAN}

Seni kaligrafi Islam merupakan komponen yang dapat melengkapi keindahan tulisan AlQur'an, dengan memiliki etika dan estetika (Abdullah Yusof, 2004: 7). Kaligrafi merupakan tulisan indah, dalam hal ini kaligrafi Islam, maka yang dimaksudkan adalah kaligrafi ayat Al Quran, yang ditulis atau dibuat secara indah. Dibuat seindah mungkin, baik bentuk maupun warnanya, tetapi tidak menghilangkan kaidah-kaidah tulis apalagi merubah bacaan dan artinya. Kaligrafi Islam dibuat untuk menyalin ayat-ayat Al Quran atau hadist, yang sekaligus untuk memperindah tempattempat tertentu, baik di dinding atau bagian lain dari suatu bangunan, maupun pada media khusus seperti kertas atau kanvas.

Salah satu cabang seni Islam yang tergolong seni visual adalah Kaligrafi dalam bahasa Arab disebut "Al-Khat". Seni Ini menduduki posisi penting dalam kebudayaan Islam. Menurut Sayeed Hoseen Nasr (1987) "Kaligrafi termasuk seni yang tinggi, karena ia menjadi symbol kesenian Islam karena perkembangannya sejalan dengan perkembagan ruh AL-Quran." Didukung oleh ayat-ayat AlQuran sebagai motivator dan sumber aspirasinya yaitu "QS. 'Alaq" dan surah "Nun". Sementara di Indonesia perkembangannya tidaklah begitu ketinggalan karena kaligrafi merupakan media dalam penyampaian ilmu pengetahuan dan dapat dijadikan sebagai media pembelajaran Agama Islam. Untuk mengembangkannya diperlukan metodologi yang sesuai sehingga kaligrafi ini dapat berkembang seiring dengan perkembangan ilmu Agama Islam. 
Tujuan lain penciptaan kaligrafi Islam adalah untuk "mempengaruhi" dan "menyentuh" jiwa pembaca, agar lebih tunduk dan mengagungkan sang Khaliq, meningkatkan keimanan dan ketakwaan, serta memahami arti ayat yang dilukiskan.

Madrasah Aliyah (MA) sebagai sekolah yang basic-nya dominan pendidikan agama Islam, maka tepatlah pelatihan ini diberikan. Selain sudah menjadi pelajaran utama seni baca dan tulis Al Quran, maka kemampuan pembuatan kaligrafinya juga mesti dimiliki para siswa. Kaligrafi Islam ini sendiri tentu bukan hal yang asing bagi para siswa MA, tetapi sepanjang pengamatan penulis baru sebatas kaligrafi di media kertas. Kaligrafi di media lain belum diperkenalkan kepada siswa, seperti kaligrafi bahan limbah kayu maupun bahan bekas lainnya.

Termasuk pengenalan teknik-teknik pembuatan kaligrafi selain teknik tulis belum diberikan kepada siswa. Dalam bidang pembuatan kaligrafi Islam dengan bahan dan media yang beragam, maka teniknyapun sangat beragam. Mulai teknik ukir dan tatah, teknik raut, teknik scrool, teknik tempel, kolase, montase, mozaik, teknik cetak, dan lainnya.

Pelatihan ini dalam upaya peningkatan kreativitas serta apresiasi seni kaligrafi Islam di MAN 3 Padangpanjang. Pelatihan pembuatan kaligrafi Islami dari bahan kayu limbah atau kayu sisa serta bahan limbah plastik ini dapat memberikan pengetahuan, wawasan, apresiasi, motivasi untuk lebih dekat dan cinta akan budaya Islam. Di samping itu untuk menanamkan sikap kepedulian generasi muda terhadap limbah, peduli lingkungan, sesuatu yang dalam keseharian dianggap tidak berharga, menjadi sesuatu yang mempunyai nilai seni dan kemanfaatan.

Limbah dalam hal ini adalah buangan yang dihasilkan dari suatu proses produksi baik industri maupun domestik (rumah tangga), yang lebih dikenal sebagai sampah, yang kehadirannya pada suatu saat dan tempat tertentu tidak dikehendaki lingkungan karena tidak memiliki nilai ekonomis (Widjajanti, 2009:1). Salah satu jenis limbah yang dapat digunakan untuk bahan pembuatan kaligrafi adalah limbah kayu, plastik, kertas, dan lainnya.Budaya masyarakat Padangpanjang yang islami dan keberadaan limbah kayu yang berlimpah di lingkungan, baik sisa dari pengolahan dan penebangan kayu di hutan, perladangan, dan di penggergajian kayu/sawmill, maupun di sentrasentra pembuatan perabotan dan mebel merupakan suatu potensi yang sangat cocok untuk dikembangkan menjadi karya seni, dalam hal ini kaligrafi Islam. Menanamkan kepedulian terhadap kayu limbah, yang meskipun berupa limbah tetap merupakan merupakan sebuah potensi dan dapat dimanfaatkan untuk sesuatu yang berguna, salah satunya untuk karya seni. Di samping itu pelatihan pembuatan kaligrafi Islam ini juga berupaya untuk menumbuh kembangkan minat dan bakat di kalangan para siswa. Dalam kurikulum yang ada di sekolah-sekolah sangat sedikit sekali porsinya, maka untuk memberikan tambahan pengalaman, apresiasi dibutuhkan pelatihan dan penyuluhan di samping penunjang mata pelajaran yang lain.

Dalam pelajaran kesenian mencakup semua cabang seni yang terkadang sulit para guru untuk menguasai materinya. Dapat dipastikan porsi untuk materi seni rupa semakin kecil, bahkan bisa saja ditiadakan digantikan oleh sang guru dengan materi cabang seni lain yang dikuasainya. Jadi kepekaan estetika dan jiwa seni di sekolah perlu diberikan dalam bentuk ekstrakurikuler. apalagi keterkaitan antara seni rupa dan mata pelajaran lain saling mendukung. Maka dari kenyataan yang ada perlu diadakan kegiatan pelatihan kaligrafi ini

Pelatihan pembuatan kaligrafi Islam dari kayu limbah dan bahan lainnya pada para siswa MAN 3 Padangpanjang dilaksanakan, karena selain ketersediaan bahan baku kayu limbah yang melimpah juga secara teknis pembuatannya mudah dipahami dan dipraktekkan.

Demikianlah situasinya, sehingga pengabdian ini merupakan usaha berlanjut dari pengembangan dan pembinaan apresiasi dan kreativitas seni di sekolah yang diharapkan mempunyai sensitivitas terhadap seni dalam rangka mengasah kemampuan sense of belonging. Di samping juga memperkenalkan ISI Padangpanjang sebagai lembaga kesenian yang dimiliki oleh masyarakat Sumatera Barat, sekaligus memanfaatkan tenaga pengajar dalam ajang menimba ilmu kesenian secara komprehensif.

\section{METODE PELAKSANAAN PENGABDIAN}

Pelaksanaan pengabdian pembuatan kaligrafi dari limbah dilakukan dengan pelatihan lansung. Peserta dibekali teori dan praktek dalam pembuatan khat-khat kaligrafi, kemudian pemindahan ke media. Serta pemilihan bahan limbah serta pembuatan kaligrafi. Latihan ini dilakukan berulang kali 
sampai peserta mampu membuat sendiri kaligrafi dari bahan limbah tersebut. Tahapan pelaksanaan pengabdian sebagai berikut.

\subsection{Metode Ceramah.}

a) Memberikan penjelasan tentang metode perancangan dan pembuatan kaligrafi Islam. Didahului dengan memberikan pengetahuan tentang khat-khat yang ada dalam kaligrafi Islam, karakter serta contoh visualisasinya. Dilanjutkan dengan memberikan materi wujud-wujud kaligrafi Islam yang ada, baik bahan maupun teknik pembuatannya. Saat ini sudah ada kaligrafi Islam berteknologi canggih, seperti mengandalkan cahaya listrik. Maka melalui perancangan dan pembuatan kaligrafi Islam Islam ini dapat membantu meningkatkan pemahaman dan pengetahuan pembuatan kaligrafi Islam. Meskipun kaligrafi yang dibuat tidak sama dengan trend terkini, tetapi dapat membuat beberapa kaligrafi yang memiliki nilai inovasi, dari aspek bahan dan teknik.

b) Memberikan penjelasan kepada guru dan siswa tentang bahan dan peralatan yang digunakan mulai dari proses perancangan, desain sampai ke pembuatan kaligrafi dan finishing.

\subsection{Metode Demonstrasi/ Praktek}

Perancangan dan pembuatan kaligrafi diawali pembuatan sketsa, penyiapan bahan dan peralatan, pemotongan triplek alas sesuai ukuran yang dibutuhkan, pemindahan desain, dan penyusunan material, pengeringan, penghalusan, serta finishing.

Guru dan siswa diberi kesempatan untuk mempraktekkannya sesuai dengan langkah-langkah yang telah didemonstrasikan sampai pembuatan kaligrafi selesai dilakukan.

\subsection{Metode Tanya-Jawab}

Hal-hal yang kurang dipahami dari ceramah dan demonstrasi dibahas dalam diskusi terbuka antara tim pengabdian dan peserta. Termasuk menampung pemikiran dan ide-ide dari peserta.

\section{HASIL DAN PEMBAHASAN}

Pengabdian ini kegiatan merancang dan membuat kaligrafi Islam dari bahan limbah kayu, plastik dan bahan lainnya. Hasil yang dicapai untuk 10 (sepuluh) kali pertemuan sesuai yang diharapkan. Beberapa tahapan persiapan dan perancangan model kaligrafi dilakukan tim pengabdian berulangkali, diluar jadwal tersebut. Hal ini mengingat sesuai bentuk kegiatan pengabdian membuat kaligrafi Islam dari bahan limbah, maka tidak harus dan tidak selalu bisa lansung dilakukan di lokasi pengabdian. Ada kalanya tim pengabdian hadir di lokasi pengabdian dengan membawa bahan dan alat yang telah siap pakai. Perancangan dan penyiapan konsep, bahan dan alat serta teknis tersebut dilakukan sebelum kegiatan pengabdian dilakukan setiap tahapnya, serta dilakukan minimal 1 (satu) hari sebelum pelaksanaan pengabdian.

Rincian pelatihan di lokasi yang telah dilakukan sebagai berikut:

\subsection{Pertemuan 1: hari Sabtu, 4 Agustus 2018, pukul 14.00 sd 16.30 WIB.}

Pertemuan pertama diisi sillaturahim dan perkenalan dengan peserta dan guru pendamping, untuk menyamakan persepsi tentang kegiatan pengabdian yang akan dilaksanakan. Memberikan penjelasan kepada peserta pelatihan, tentang materi kegiatan yang akan dilakukan selama selama pelatihan. Terutama bagaimana merancang dan membuat kaligrafi Islam dari bahan limbah, serta kelengkapan pendukung dalam pembuatan kaligrafi tersebut. Kegiatan utama bukanlah melatih bagaimana membuat khat-khat kaligrafi di media kertas, melainkan membuat kaligrafi dari bahan limbah, dengan desain khat yang sudah disiapkan tim pengabdian.

Memberikan pemahaman kepada peserta untuk memperhatikan kaidah-kaidah ketepatan penulisan dan pembuatan huruf sesuai karakter khat yang digunakan, agar arti dari kalimah kaligrafi yang dibuat tidak salah.

Pada awal proses perancangan penting diperhatikan jenis khat yang akan digunakan, kemudian media dan teknik perwujudan kaligrafi. Karena tidak semua jenis khat cocok dibuat dengan bahan dari limbah. Termasuk pemilihan jenis limbah serta warnanya, agar huruf-huruf kaligrafi dan tanda bacanya "hidup" dan terbaca dengan baik. 
Pertemuan awal ini juga diberikan informasi dan pengetahuan tentang perkembangan kaligrafi dari bahan limbah sejenis yang akan digunakan. Melalui slide-slide, gambar dan audio-vidio. Dengan harapan siswa dan guru pendamping semakin memahami kaligrafi yang akan dibuat.

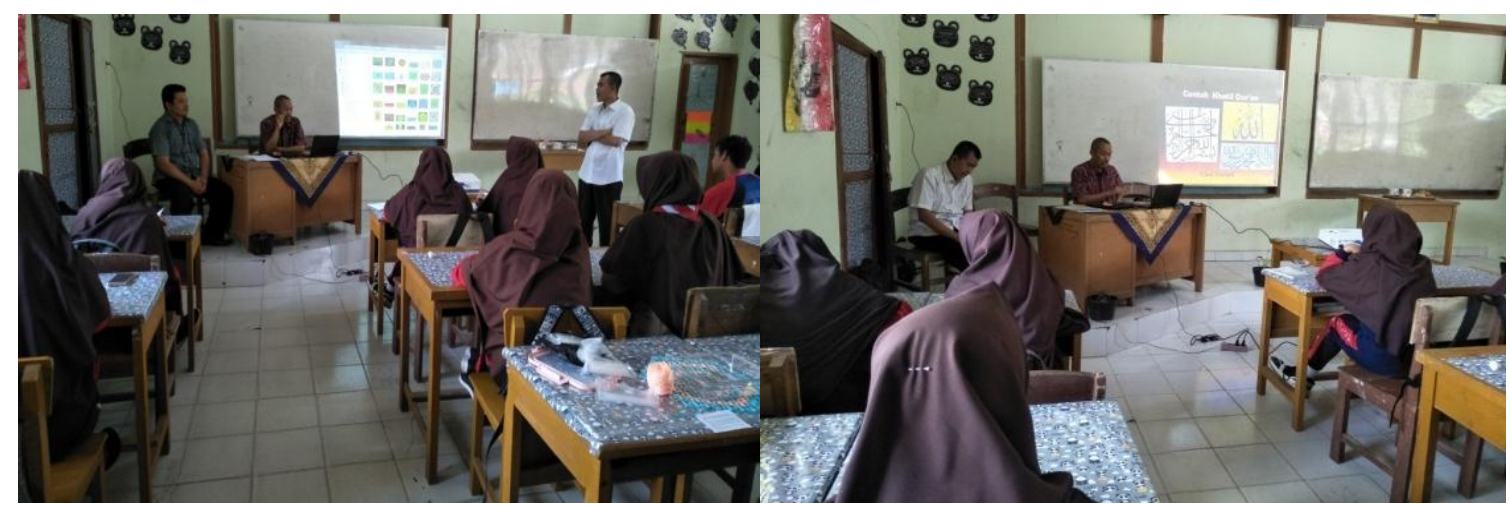

Gambar 1. Materi Pengenalan Khatil Kaligrafi Islam

Presentasi pengenalan khat-khat kaligrafi yang ada, mulai dari khat Tsulut, khat Diwani Jali, khat Kufi, khat Naskhi dan khat Farisi. Jenis-jenis khat tersebut dijelaskan bersamaan dengan contohcontohnya, serta trend perkembangannya saat ini dalam seni kaligrafi Islam.

Kegiatan dilanjutkan latihan membuat masing-masing jenis khat tersebut, di media kertas manila dengan pensil, kemudian bollpoint dan diblok dengan tinta cina. Kaligrafi yang dibuat adalah kalimah Allah dan Muhammad. Melalui latihan pembuatan khat ini peserta lebih memahami karakter dari masing-masing khat, serta mempermudah dalam pengaplikasiannya ke media triplek dan limbah. Selain itu juga peserta dapat memilih khat yang tepat untuk dibuat sesuai karakter limbah yang digunakan.

Pertemuan pertama ini diikuti oleh peserta dua puluh orang siswa dan satu orang guru pendamping, sesuai kesepakatan dengan sekolah sebelumnya. Peserta terdiri dari kelas 11 dan 12, baik putra maupun putri. Tempat pelatihan diutamakan di dalam kelas dan di pendopo sekolah, serta di mushola. Tempat situasional, sesuai kebutuhan dan keadaan. Kalau tidak ada kelas yang bisa dipakai, maka kegiatan pelatihan dilaksanakan di pendopo atau di mushola.

\subsection{Pertemuan ke-2: hari Sabtu, 1 September 2018, pukul 14.00 sd 16.00 WIB.}

Pertemuan kedua diisi praktek pembuatan kaligrafi di media kanvas. Kanvas berukuran 80 x 60 $\mathrm{Cm}$, dalam kondisi siap pakai. Pembuatan kaligrafi pada media kanvas ini dilakukan dengan teknik satu kanvas untuk dua orang siswa. Kaligrafi yang dilukis adalah desain yang dibuat sebelumnya pada kertas. Melukis menggunakan cat akrilik.

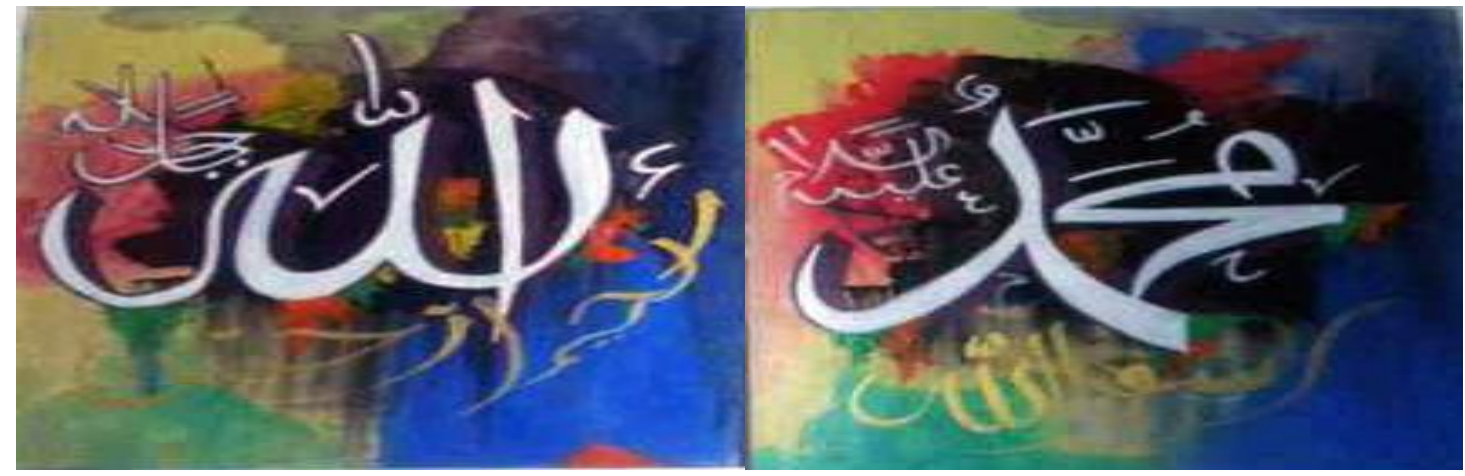

Gambar 2. Kaligrafi Kalimah Allah dan Muhammad di Media Kanvas

Dalam penggarapannya menggunakan teknik blok, sama seperti pada media kertas, tetapi peserta diberi kebebasan dalam aplikasinya, sesuai kreativitas masing-masing, termasuk pemilihan bentuk huruf atau khat. Pembuatan kaligrafi pada kanvas ini tidak tuntas pada pertemuan kedua, maka peserta diberi kesempatan untuk melanjutkan di waktu yang lain. 


\subsection{Pertemuan ke-3; hari Sabtu, 8 September 2018, pukul 14.00 sd 16.30 WIB}

Pertemuan ketiga, praktek pembuatan kaligrafi dari bahan limbah cangkang telur, untuk perekatnya menggunakan lem putih. Alas atau media menggunakan triplek tebal $4 \mathrm{~mm}$, dipotong ukuran 40 x $40 \mathrm{~cm}$. Kaligrafi yang dibuat adalah kalimah Allah dan Muhammad, khat suluts.
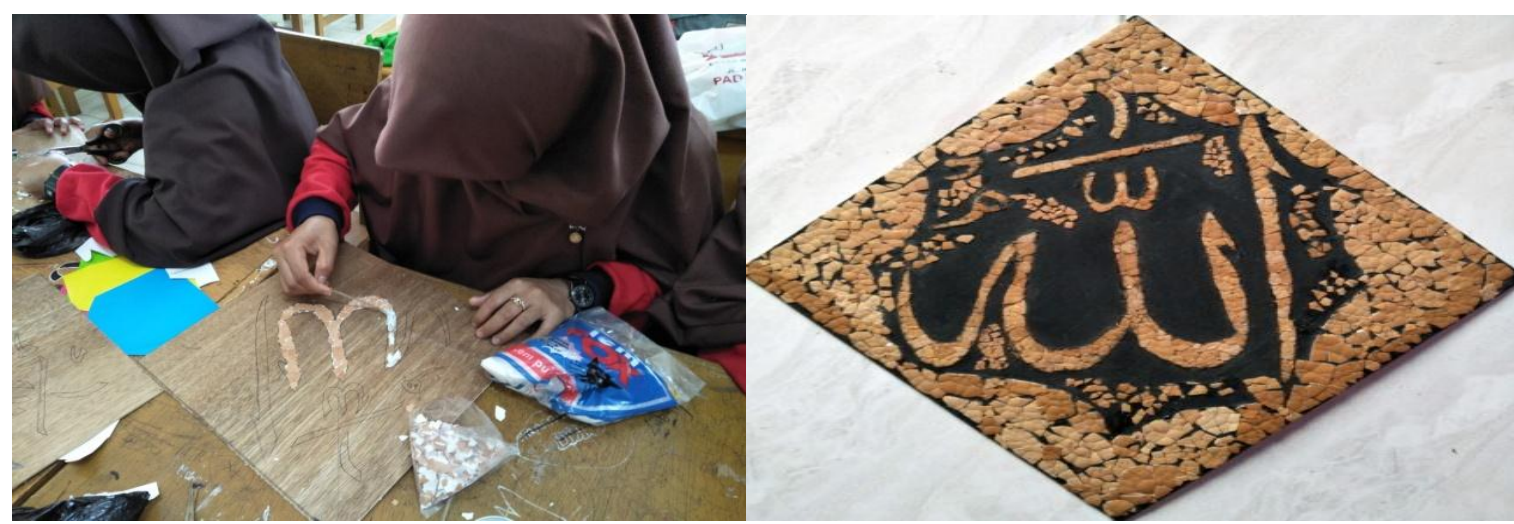

Gambar 3. Pelatihan Pembuatan Kaligrafi Kalimah Allah dari Cangkang Kulit Telur

Langkah awal adalah memindahkan desain kalimah Allah dan Muhammad ke media triplek menggunakan pensil dan kertas duplikator. Cangkang telur dipotong kecil-kecil, kira-kira ukuran $0,5 \times 0,5 \mathrm{~cm}-1 \mathrm{~cm} \times 1 \mathrm{~cm}$. Pemotongan cangkang kulit telur menggunakan gunting, atau diremukkan dengan tangan. Cangkang kulit telur yang digunakan adalah yang sudah dibersihkan dari sisa putih telur, serta telah dikeringkan melalui proses penjemuran, sehingga kulit ari bagian dalam cangkang sudah terkelupas.Penempelan cangkang kulit telur ayam secara bertahap, satu demi satu ke dalam area garis huruf dan tanda bacanya. tempelan cangkang telur pada huruf dan tanda baca yang keluar dari garis sket atau desain huruf dan tanda bacanya dirapikan menggunkan pisau cutter.

Area background ditempeli cangkang telur diatur sedemikian rupa sesuai desain tertentu. Bagian yang tidak tertutup cangkang telur ditutup dengan tinta cina menggunakan kuas. Setelah kering difinishing dengan cat semrot clear gloss.

Proses pengolahan bahan, pembuatan kaligrafi hingga pengeringan dan finishing, dicatat dan didokumentasikan kemudian diarsipkan untuk peserta agar dapat diikuti dan dilakukan oleh peserta meskipun tanpa ada pelatih.

\subsection{Pertemuan ke-4; hari Sabtu, 15 September 2018, pukul 14.00 sd 16.30 WIB}

Pertemuan keempat pembuatan kaligrafi dari bahan kulit batang pisang. Kulit batang pisang yang digunakan adalah yang sudah dikeringkan terlebih dahulu. Sehingga kulit batang pisang ini benar-benar tidak mengandung air sedikitpun.

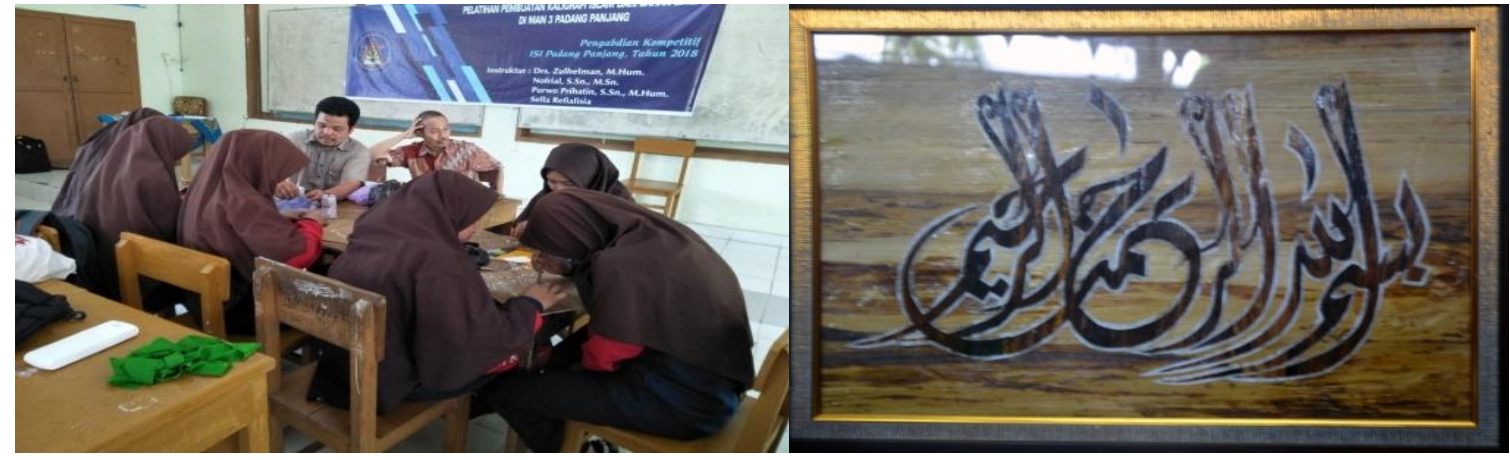

Gambar 4. Pelatihan Pembuatan Kaligrafi dari Kulit Batang isang

Kaligrafi yang dibuat adalah kalimah Basmallah. Prosesnya sama dengan pembuatan kaligrafi dari bahan cangkang telur, di mana media triplek sebagai alas disiapkan terlebih dahulu, kemudian ditempelkan kulit batang pisang secara menyeluruh, sehingga memenuhi seluruh permukaan alas triplek. Sketsa kalimah Basmallah printout kertas ditempelkan ke kulit batang pisang secara 
terbalik. Setelah kering desain kalimah Basmallah dipotong dengan gunting, mengikuti bentuk huruf. Posisi gunting di luar garis huruf, kemudian ditempelkan pada alas. Setelah kering diberi kontur huruf dengan spidol silver, kemudian difinishing dengan clear gloss, serta diberi pigura dan kaca.

\subsection{Pertemuan ke-5; hari Sabtu, 22 September 2018, pukul 10.00 sd 12.30 WIB}

Pertemuan kelima diisi dengan pembuatan kaligrafi kalimah Allah dan Muhammad dengan bahan utama serbuk gergaji atau serbuk kayu. Sebagai media kaligrafi menggunakan triplek. Bahan lainnya adalah lem putih atau lem kayu untuk perekat serbuk kayu. Bahan lainnya adalah pigura.

Alat yang digunakan dalam proses pembuatan kaligrafi adalah; a). Tapisan atau tirisan santan kelapa untuk menyaring dan membersihkan serbuk gergaji, karena yang akan digunakan adalah serbuk gergaji yang halus. b). Baskom kecil, digunakan untuk wadah mengaduk serbuk gergaji dengan lem, yang ditambahkan sedikit air. c). Cetakan, cetakan menggunakan negatif kaligrafi kalimah Allah dan Muhammad, yang didesain dan dibuat terlebih dahulu dari kayu yang di scrool. Adonan serbuk gergaji dan lem dimasukkan ke cetakan, dengan sedikit ditekan. Cetakan digunakan untuk membentuk adonan serbuk gergaji menjadi kaligrafi. Kalimah Allah dan Muhammad lansung dicetak di atas media triplek. Cetakan diangkat dalam kondisi adonan masih basah. Agar adonan tidak pecah dan terangkat bersamaan dengan cetakan, maka sebelumnya cetakan dilumuri oli bekas, serta waktu cetakan diangkat adonan ditekan.

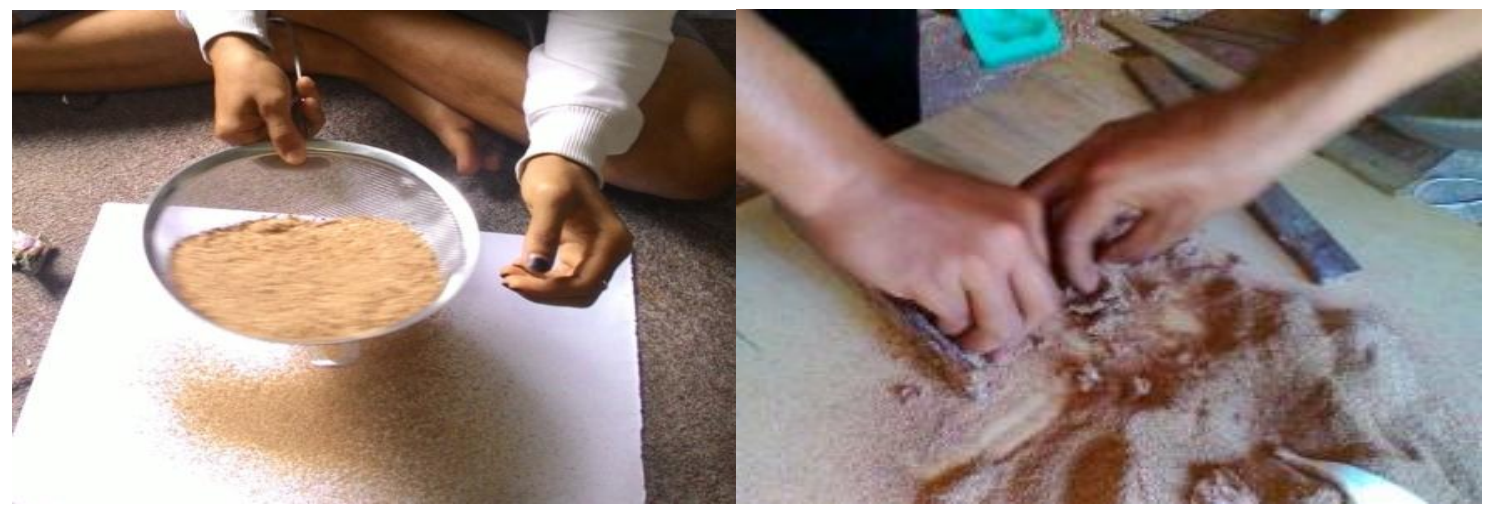

Gambar 5. Pengolahan serbuk Gergaji untuk pembuatan Kaligrafi

\subsection{Pertemuan ke-6; hari Sabtu, 29 September 2018, pukul 14.00 sd 16.30 WIB}

Pertemuan keenam, diisi dengan kegiatan membersihkan kaligrafi hasil cetakan pada pertemuan sebelumnya. Hasil cetakan cukup bagus, pembersihan dilakukan dengan cara dirapikan dengan pisau cutter, kemudian diampelas. Kemudian difinishing dengan cat semprot clear gloss, serta sebahagian ada yang diwarnai terlebih dahulu dengan cat akrilik. Setelah kering diberi pigura.

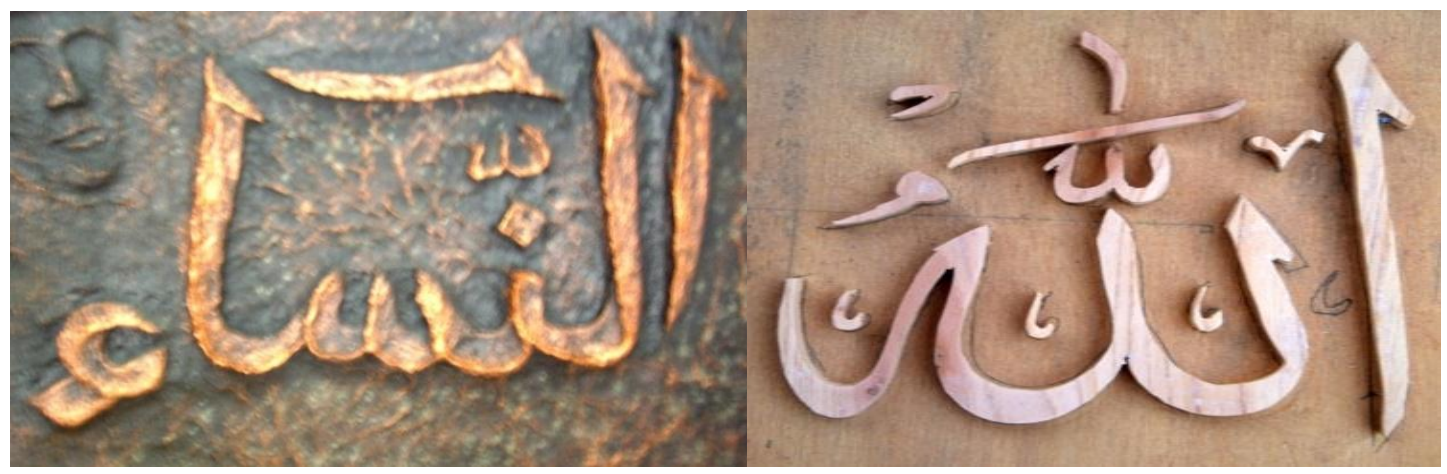

Gambar 6. Kaligrafidari serbuk Gergaji

\subsection{Pertemuan ke-7; hari Sabtu, 6 Oktober 2018, pukul 14.00 sd 16.30 WIB}

Pertemuan ketujuh diisi dengan pembuatan kaligrafi dari pecahan cermin dan plastik limbah kemasan. Disediakan dua bahan, agar peserta ada pilihan, mereka dibebaskan bagi yang ingin memilih apakah limbah plastik atau pecahan cermin. 
Pecahan cermin yang digunakan tebal 3mm, sisa-sisa pemotongan di tukang kaca, serta limbah cermin pecah. Limbah plastik yang digunakan adalah kemasan makanan, seperti kemasan minyak goreng, kecap sachet, sabun cair sachet, sampo sachet dan lainnya. Limbah plastik yang digunakan ini dipilih yang tebal dan keras, dengan warna-warna yang cerah.

Alat yang digunakan adalah palu kecil, untuk memecahkan ulang potongan-potongan cermin. Gunting dan pisau cutter, digunakan untuk memotong dan merapikan limbah plastik, sesuai kebutuhan dalam pembuatan kaligrafi.

Pembuatan kaligrafi dari pecahan cermin, diawali pemindahan desain kaligrafi kalimah Allah dan Muhammad ke media triplek, setelah itu dilumuri lem kayu/lem putih. Kemudian ditempelkan pecahan cermin satu persatu, sampai memeuhi seluruh huruf dan tanda baca huruf. Setelah lem kering maka, untuk background dilumuri lem dan disiram serbuk cermin. Serbuk cermin dihaluskan dengan cara pecahan cermin ditumbuk dengan palu di atas batu atau tembok.

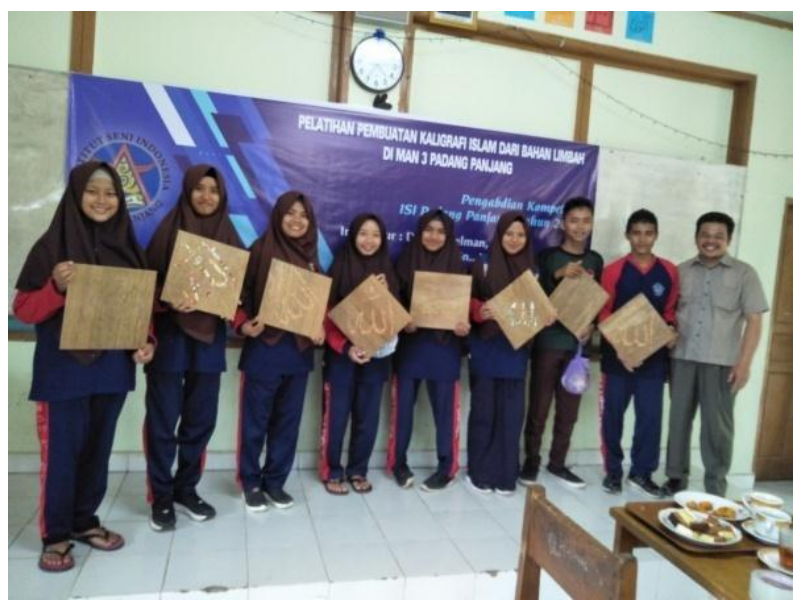

Gambar 7. Peserta dengan karya kaligrafi dari bahan limbah plastik dan kertas

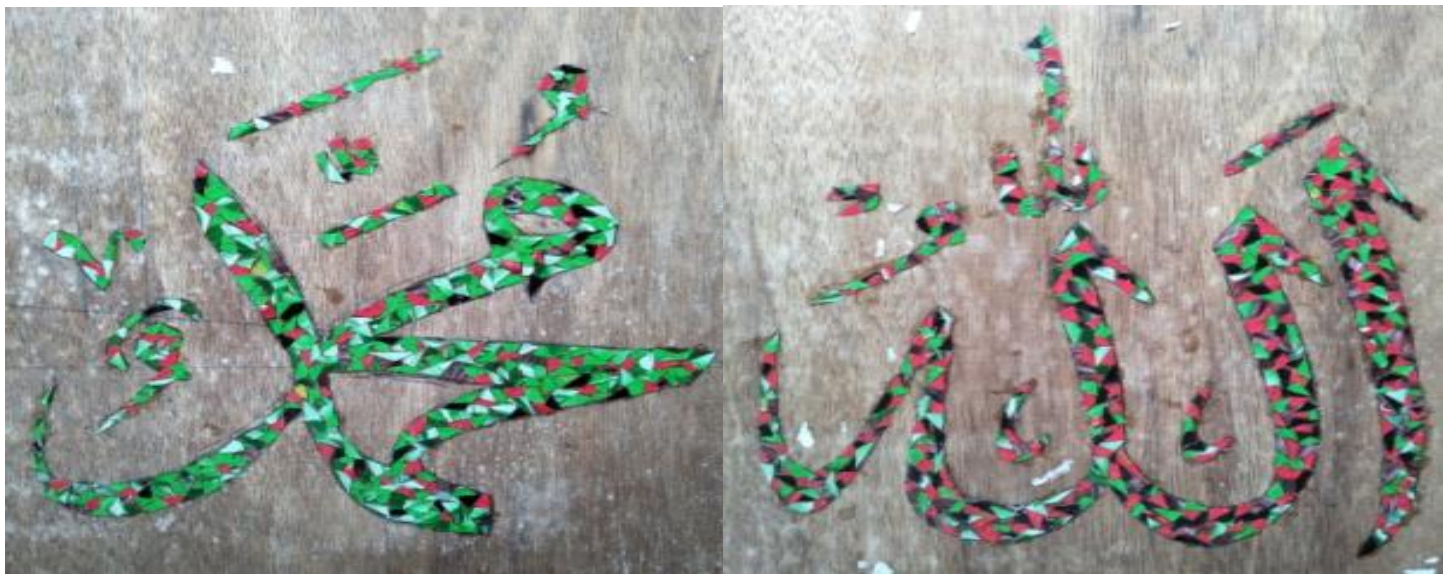

Gambar 8. Kaligrafi dari bahan limbah kertas 


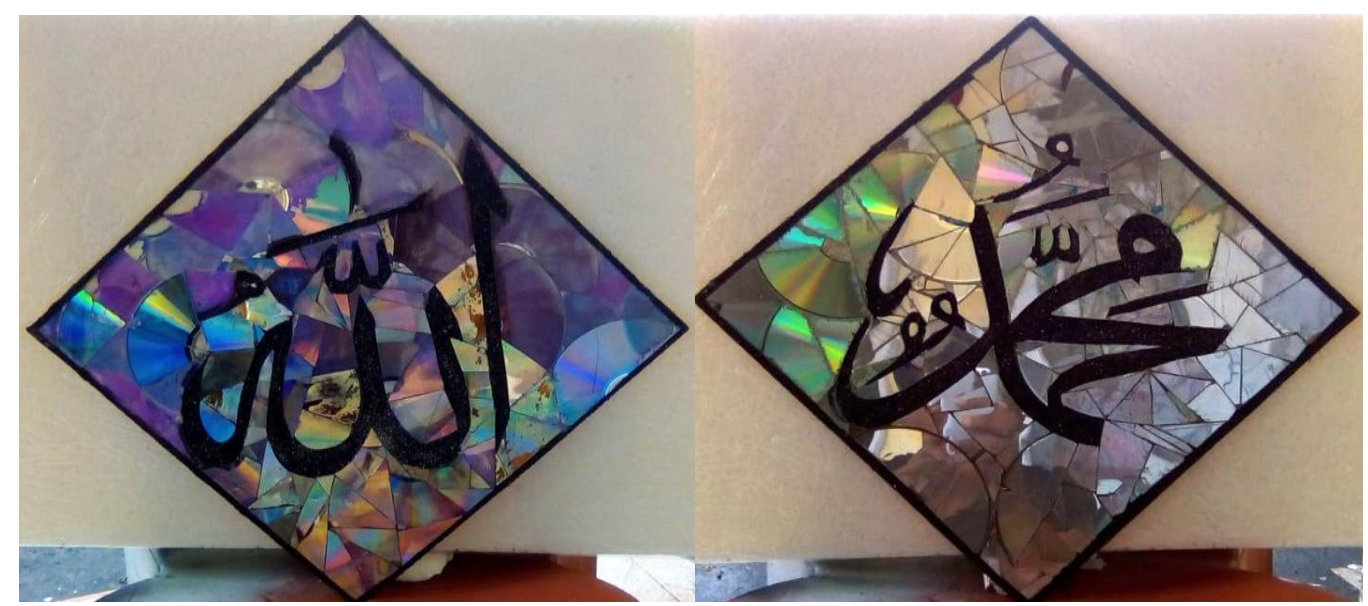

Gambar 9. Kaligrafi dari bahan limbah Cermin

Pembuatan kaligrafi dari bahan limbah plastik juga dimulai dari penyiapan desain kalimah Allah dan Muhammad di media triplek tersebut. Plastik kemasan dipotong kecil-kecil kira-kira ukuran $0,5 \times 0,5 \mathrm{~cm}-1 \mathrm{x} 1 \mathrm{~cm}$, kemudian ditempelkan menggunakan lem aibon. Penyusunan plastik diatur sedemikian rupa agar terdapat gradasi warna. Untuk background plastik limbah dipotong kecilkecil hampir menjadi serbuk, kemudian ditabur ke bagian triplek yang menjadi background, terlebih dahulu triplek dilumuri lem. Setelah proses pembuatan kaligrafi baik bahan pecahan cermin maupun bahan limbah plastik selesai dan kering, difinishing dengan cat semprot clear gloss serta diberi pigura.

\subsection{Pertemuan ke-8; hari Sabtu, 13 Oktober 2018, pukul 14.00 sd 16.30 WIB}

Pertemuan kedelapan diisi dengan pembuatan kaligrafi dari kerikil dan batok kelapa. Kerikil yang digunakan dipilih ukuran antara $0,5 \times 0,5 \mathrm{~cm}-1 \times 1 \mathrm{~cm}$. Kerikil yang digunakan adalah kerikil dari sungai, yang bentuknya bulat atau petak, serta dipisahkan antara yang berwarna putih, abuabu, coklat dan hitam.

Sementara itu batok, kelapa yang digunakan adalah yang sudah tua, sehingga warnanya berwarna hitam. Tempurung kelapa diketok dan dipecahkan kecil-kecil, atau dibentuk sesuai kebutuhan bentuk huruf di kaligrafi.

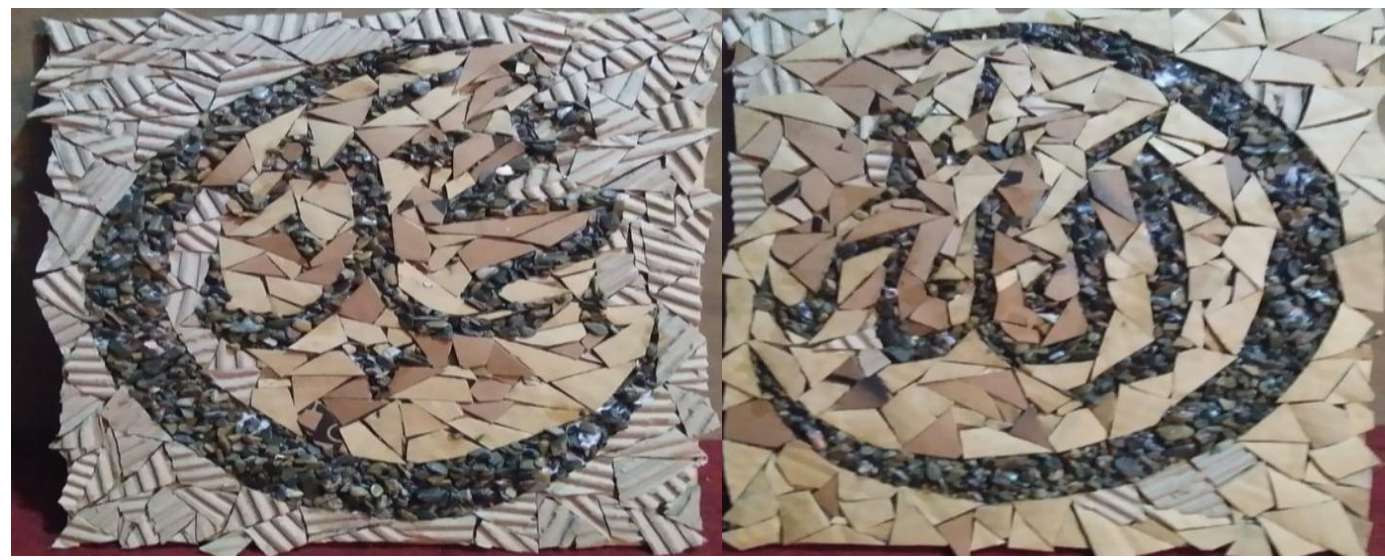

Gambar 10. Kaligrafi dari bahan pasir dan batok kelapa

Pembuatan kaligrafi dari kerikil dan batok kelapa prosesnya sama, diawali pemindahan desain kaligrafi kalimah Allah dan Muhammad ke media triplek, setelah itu dilumuri lem kayu/lem putih. Kemudian ditempelkan kerikil atau pecahan batok kelapa satu persatu, sampai memeuhi seluruh huruf dan tanda baca huruf. Setelah lem kering maka, untuk background baik bahan kerikil maupun batok kelapa dilumuri lem dan disiram pasir halus. Setelah proses pembuatan kaligrafi baik bahan kerikil maupun pecahan batok kelapa selesai dan kering, selanjutnya difinishing dengan cat semprot clear gloss serta diberi pigura. 


\subsection{Pertemuan ke-9; hari Sabtu, 27 Oktober 2018, pukul 14.00 sd 16.30 WIB}

Pertemuan kesembilan dilakukan dengan kegiatan pembuatan kaligrafi dari bahan kayu perca. Bahan yang digunakan adalah potongan-potongan kayu olahan, sisa pembuatan mebel dan lain sebagainya, yang sudah tidak akan dipakai lagi. Bahan atau kayu limbah ini disamakan terlebih dahulu ketebalannya sebelum digunakan, yakni $0,5 \mathrm{~cm}$. Bahan lainnya adalah lem putih atau lem kayu, lem cair atau lem G. Untuk media atau alas karya menggunakan triplek.

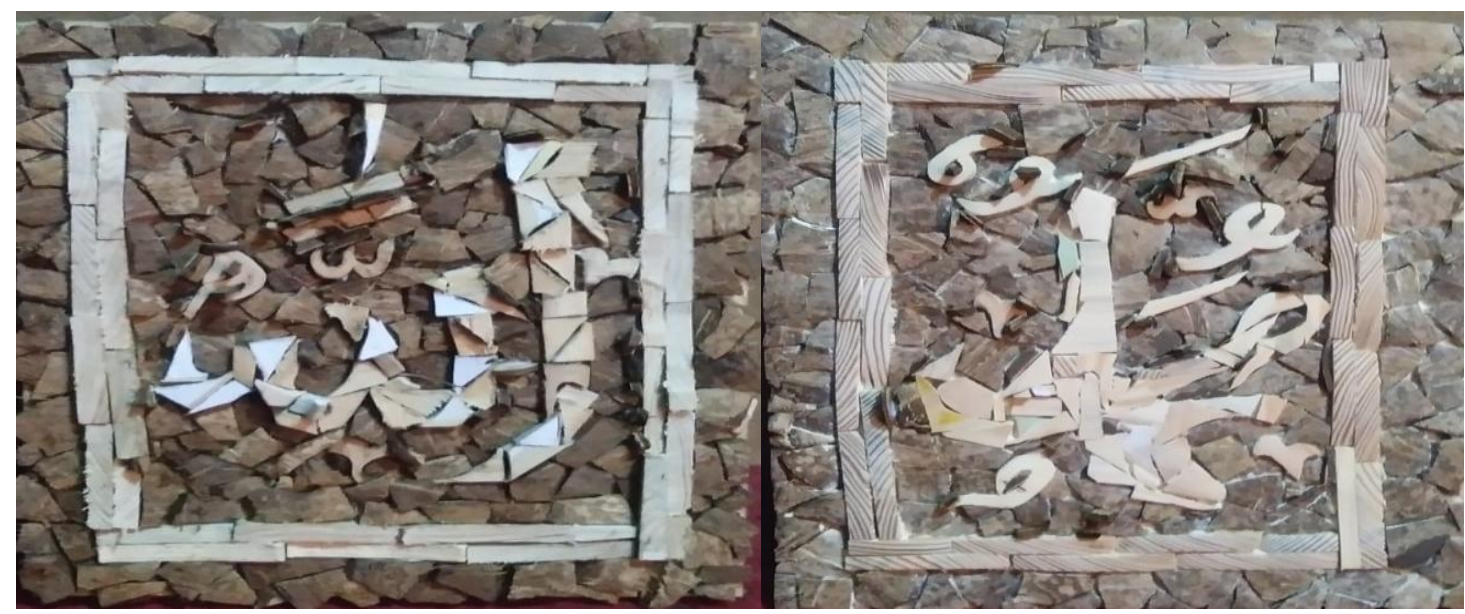

Gambar 11. Kaligrafi dari bahan kayu Perca

Peralatan yang digunakan adalah gergaji scrool, gergaji potong, pahat dan pisau cutter. Langkah pembuatan kaligrafi dari kayu perca ini dimulai dari pemindahan desain kalimah Allah dan Muhammad ke media triplek. Dilanjutkan pemilihan kayu perca kemudian dipotong dengan gergaji scroll manual, sesuai desain huruf. Pembuatan huruf sedikit demi sedikit, sesuai lebar kayu perca dan ukuran huruf yang dibuat. Antara satu kayu perca dan kayu berikutnya diusahakan warna dan tekstur kayu berbeda, agar ada gradasi dan variasi warna kayu pada kaligrafi tersebut. Setelah kebutuhan untuk semua huruf dan tanda baca selesai dibuat dan disusun, langkah selanjutnya dilakukan proses pengeleman. Pengeleman dilakukan satu persatu, mulai dari pangkal huruf kemudian ke ujung huruf, kemudian tanda baca.

Setelah semua huruf dan tanda baca selesai ditempel, maka langkah selanjutnya dilakukan penaburan lem pada seluruh area alas dan background, kemudian dilakukan penyiraman serbuk kayu gergajian secara merata untuk pembuatan tekstur background.

\subsection{Pertemuan ke-10; hari Sabtu, 03 November 2018, pukul 14.00 sd 16.30 WIB}

Pertemuan kesepuluh atau pertemuan terakhir diisi dengan finishing karya kaligrafi dari perca kayu. Langkah pertama pengamplasan, kemudian pemberian warna pada background menggunakan cat akrilik, dilanjutkan finishing akhir dengan cat semprot clear gloss. Setelah finishing selesai dilaksanakan diberi pigura.
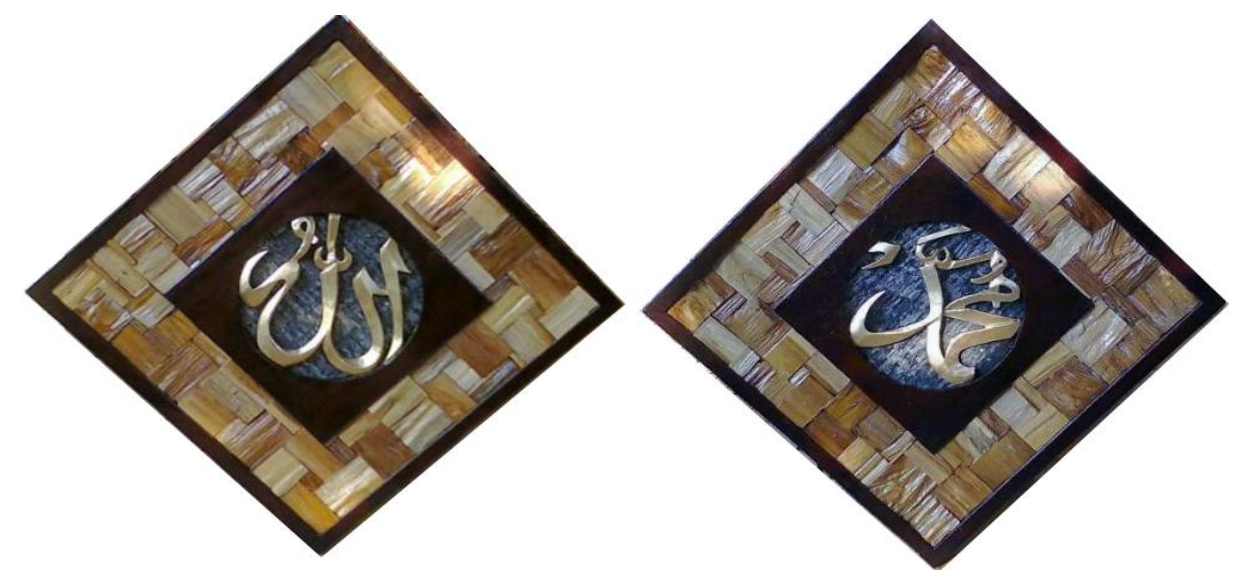

Gambar 12. Kaligrafi dari bahan kayu Perca 
Di pertemuan terakhir ini juga dilaksanakan pemajangan semua hasil pelatihan. Mulai dari bahan cangkang kulit telur sampai ke perca kayu. Dilakukan evaluasi, kritik dan saran, baik terkait teknik, desain, bahan serta alat. Termasuk konsep dan teknis pelaksanaan pengabdian secara umum.

\section{KESIMPULAN}

Pengabdian pada masyarakat dalam hal ini adalah Pelatihan Pembuatan Kaligrafi Islam dari Bahan Limbah di MAN 3 Padangpanjang sudah terlaksana sesuai rencana sesuai rencana, mulai tanggal 4 Agustus sampai 3 November 2018 yang bertempat di MAN 3 Padangpanjang. Secara umum kegiatan berjalan sesuai dengan yang telah direncanakan. Delapan bahan limbah berhasil digunakan untuk pembuatan kaligrafi, dibuat dengan baik oleh peserta. Pelatihan pembuatan kaligrafi Islam dari bahan limbah yang telah dibuat adalah dari bahan limbah cangkang kulit telur, limbah serbuk kayu, pecahan cermin, batok kelapa, kulit batang pisang, limbah plastik dan kertas, kayu perca dan kerikil, serta kaligrafi pada media kertas dan kanvas.

Guna terwujudnya hasil yang maksimal tentu ada follow up dari kegiatan pelatihan ini, sebab betapapun berhasilnya sebuah kegiatan pelatihan ini tetapi jika tidak ada kesadaran dan keinginan dari peserta dan sekolah untuk mengaplikasikan serta mengembangkannya tentu kegiatan ini akan menjadi sia-sia saja dan belum dikatakan berhasil.

\section{DAFTAR PUSTAKA}

Yusof, Abdullah. 2004. Seni Islam. UMCCed, Siri Pengajian Ushuluddin Universiti Malaya, Kuala Lumpur

Nars, Seyeed Hossein. 1987. Islamic Art and Spirituality, Golgonooza Press, Sufflolk, UK.

Safadi, Yasin Hamid. 1986. Kaligrafi Islam, Alih Bahasa Abdul Hadi WM. PT. Pantja Simpati, Jakarta. Subarna, Abay D. dkk. 2006. Sistim Tulisan Dan Kaligrafi, LPSN, Jakarta.

Widjajanti, Endang. 2009. Penanganan Limbah Laboratorium Kimia. FMIPA UNY, Yogyakarta. 